\title{
Efektivitas Model Pembelajaran 3CM (Cool-Critical- Creative-Meaningfull) terhadap Kemampuan Berpikir Kritis Siswa SMP
}

\author{
Titania Mega Rizti ${ }^{*}$, Erlina Prihatnani ${ }^{2}$ \\ Program Studi Pendidikan Matematika, Universitas Kristen Satya Wacana \\ Jalan Diponegoro No. 52-60 Sidorejo, Salatiga, Jawa Tengah, Indonesia \\ 1*202017051@student.uksw; 2erlina.prihatnani@uksw.edu
}

Artikel diterima: 05-01-2021, direvisi: 24-05-2021, diterbitkan: 31-05-2021

\begin{abstract}
Abstrak
Pembelajaran matematika diharapkan dapat mengasah kemampuan berpikir kritis, meskipun pembelajaran secara daring. Penelitian bertujuan menerapkan salah satu model pembelajaran yang menekankan pada aspek berpikir kritis yaitu model 3CM (Cool-CriticalCreative-Meaningfull) pada materi bangun ruang sisi datar dan menganalisis dampaknya terhadap kemampuan berpikir kritis siswa. Populasi penelitian adalah seluruh siswa SMPN di Salatiga, sampelnya 82 siswa dari SMPN 1 Salatiga dan SMPN 6 Salatiga yang dibagi menjadi kelompok eksperimen 1 dan 2. Desain penelitian eksperimen semu ini adalah randomized control grup pretest-postest design. Instrumen tes berbentuk 7 soal uraian, terdiri dari pretest dan posttest dengan rubrik penilaian berdasarkan aspek Focus, Reason, Inference, Situation, Clarity, and Overview. Uji hipotesis menunjukkan penerapan model pembelajaran $3 \mathrm{CM}$ dengan dua jenis kegiatan creative yang berbeda yaitu berbasis project dan berbasis problems posing menghasilkan kemampuan berpikir kritis yang sama. Penerapan 3CM dimungkinkan untuk menggunakan dua jenis kegiatan tersebut dalam melakukan aspek creative guna mengasah kemampuan berpikir kritis siswa. Kata Kunci: bangun ruang sisi datar, berpikir kritis, 3CM, FRISCO.
\end{abstract}

The Effectiveness of The $3 \mathrm{CM}$ (Cool-Critical-CreativeMeaningful) Learning Model on The Critical Thinking Ability of SMP Students

\begin{abstract}
Mathematics learning is expected to hone thinking skills, although learning must be done boldly. This study aims to apply a learning model that emphasizes the critical thinking aspect, namely the 3CM (Cool-Critical-Creative-Meaningful) model on the flat-sided building material and analyze its impact on students' critical thinking skills. The study population was all students of SMPN in Salatiga, the sample was 82 students from SMPN 1 Salatiga and SMPN 6 Salatiga who were divided into experimental 1 and 2 groups. This quasiexperimental research design was a randomized control group pretest-posttest design. The test instrument is in the form of a description of 7 questions consisting of a pretest and posttest with a rubric based on aspects Focus, Reason, Inference, Situation, Clarity, and Overview. Hypothesis testing that the application of the $3 \mathrm{CM}$ learning model with different types of Creative (based on project and problems posing) activites results in the same critical thinking skills.

Keywords: flat-sided building, critical thinking, 3CM, FRISCO.
\end{abstract}




\section{Pendahuluan}

Salah satu kemampuan yang harus dimiliki pada abad 21 adalah berpikir kritis (Ruqoyyah dkk., 2020). Berpikir kritis penting dimiliki oleh setiap individu, karena permasalahan kehidupan sehari-hari yang semakin kompleks (Sarimanah, 2017; Rizky \& Sritresna, 2021).

Pada masa pandemi, sejak kasus Covid19 meningkat di Indonesia, berbagai permasalahan muncul di tengah masyarakat (Boer dkk.,2020). Covid-19 membawa dampak besar terhadap segala aspek, tak terkecuali dunia pendidikan (Nurdin \& Anhusadar, 2021). Dampak Covid-19 di dunia pendidikan bisa terlihat dari kebijakan pemerintah pusat hingga daerah yang meliburkan seluruh lembaga pendidikan (Nurdin \& Anhusadar, 2021) untuk beberapa waktu dan dilanjutkan dengan pembelajaran daring dengan adanya penyederhanaan kurikulum.

Pemerintah mengeluarkan Surat Edaran (SE) pada tanggal 18 Maret 2020 yang berisi tentang segala kegiatan di semua sektor sementara waktu ditunda demi mengurangi penyebaran Covid-19 terutama pada bidang pendidikan (Kemdikbud, 2020). Menteri Pendidikan dan Kebudayaan Republik Indonesia pada tanggal 24 Maret 2020 mengeluarkan Surat Edaran (SE) Nomor 4 Tahun 2020. Pada Surat Edaran tersebut dijelaskan bahwa proses kegiatan belajar dilakukan di rumah melalui pembelajaran daring atau jarak jauh. Proses kegiatan pembelajaran yang biasanya dilakukan secara tatap muka diubah menjadi pembelajaran daring atau jarak jauh guna mengurangi penyebaran Covid-19 (Wijaya dkk., 2020).
Menurut Prawiyogi dkk., (2020), pembelajaran dengan menggunakan suatu media yang memugkinkan terjadi interaksi antara pengajar dan pembelajar disebut pembelajaran daring/ jarak jauh. Proses pembelajaran jarak jauh memanfaatkan jaringan internet, sehingga siswa, guru maupun dosen memiliki keleluasaan waktu dalam pelaksanaannya (Abidin dkk., 2020). Pelaksanaan pembelajaran jarak jauh membutuhkan teknologi sebagai penunjang dengan dukungan dari perangkat mobile diantaranya: laptop, smartphone, dengan aplikasi yang menunjang seperti Whatsapp, live chat, e-learning, Edmodo, EdLink, Moodle, Google Clasroom, kelas online schoology (Astini, 2020; Dewi, 2020).

Meskipun proses pembelajaran dilakukan secara daring, diharapkan pembelajaran tetap dapat mengembangkan kompetensi 4C siswa (Baharuddin, 2020). Salah satu kompetensi 4C adalah critical thingking atau berpikir kritis. High - order mathematical thingking skill merupakan salah satu kemampuan berpikir kritis tingkat tinggi (Nurhikmayati \& Jatisunda, 2019). Siswa dituntut untuk memiliki keterampilan berpikir, keaslian ide, fleksibilitas, serta keluwesan, dalam mencari solusi dari masalah yang dihadapi sehingga kemampuan berpikir kritis sangat perlu dikembangkan pada siswa (Budhi \& Eka, 2016).

Berpikir kritis adalah berpikir reflektif dan logis yang difokuskan pada pengambilan keputusan yang akan dipercaya atau dilakukan. Sejalan dengan pendapat tersebut, Larsson (2017) mendefinisikan berpikir kritis sebagai upaya seseorang untuk memeriksa kebenaran dari suatu 
informasi menggunakan ketersediaan bukti, logika dan kesadaran akan bias. Adapun Choy \& Cheah (2009) mendefinisikan berpikir kritis sebagai proses kompleks kognitif tingkat tinggi dalam memproses informasi. Berpikir kritis merupakan keterampilan atau strategi kognitif dalam menentukan tujuan (Apiati \& Hermanto, 2020).

Berpikir kritis mencakup dua hal yaitu critical thinking ability (kemampuan berpikir kritis) dan critical thingking disposition (disposisi berpikir kritis), untuk memutuskan apa yang harus dipercaya atau dilakukan. Seseorang disebut memiliki kemampuan berpikir kritis jika dalam menerima informasi, orang tersebut berusaha membuktikan kebenaran informasi yang diperoleh dan dapat dipertanggungjawabkan bukan hanya sekedar percaya tanpa melakukan pembuktian (Susilowati dkk., 2017). Menurut Ennis (Wicaksono \& Prihatnani, 2019), orang yang memiliki kemampuan berpikir kritis idealnya memiliki lima aspek yang biasa disingkat FRISCO (Focus, Reason, Inference, Situation, Clarity, Overview). Focus yaitu menentukan hal yang menjadi fokus dalam permasalahan tersebut. Reason yaitu mengetahui alasan-alasan yang mendukung berdasarkan situasi dan fakta yang relevan. Inference yaitu membuat simpulan yang beralasan dan dapat dipertanggungjawabkan, Situation yaitu menerapkan konsep pengetahuan yang dimiliki sebelumnya untuk menyelesaikan masalah pada situasi yang lain. Clarity yaitu menjelaskan arti-arti atau istilah lain yang digunakan. Overview yaitu melakukan pengecekan atau pemeriksaan kembali terhadap langkah penyelesaian masalah. Keenam aspek tersebut saling berkaitan dan merupakan daftaran yang digunakan untuk memastikan bahwa kita telah melakukan hal-hal yang sama (Mahardiningrum, 2018).

Kemampuan berpikir juga merupakan sarana untuk mencapai tujuan pendidikan yaitu agar siswa mampu memecahkan masalah taraf tingkat tinggi. Kemampuan berpikir kritis yang dimiliki siswa akan berpengaruh terhadap kemampuan dalam menyelesaikan permasalahan yang dihadapi dalam mencapai kesuksesan.

Permasalahannya adalah belum optimalnya kemampuan berpikir kritis siswa Indonesia khususnya dalam bidang matematika (Nurhikmayati \& Jatisunda, 2019). Penelitian yang dilakukan oleh Dewi dkk (2019) juga menunjukan bahwa kemampuan berpikir kritis matematis siswa masih tergolong rendah, hal tersebut ditunjukan dengan kurang terlatihnya siswa pada situasi menguji, mempertanyakan, menghubungkan, dan mengevaluasi dalam suatu situasi.

Indonesia National Assesment Program (INAP) pada tahun 2016 menunjukan sekitar 77,13\% siswa di seluruh Indonesia memiliki kompetensi matematika yang rendah, 20,58\% siswa dikategorikan cukup dan hanya $2,29 \%$ yang masuk dalam kategori baik (Kemdikbud Balitbag-Puspendik). Sedikitnya kategori siswa yang memiliki kompetensi matematika dikarenakan kurangnya kemampuan para siswa untuk berpikir kritis terutama saat siswa dihadapkan dengan soal-soal bertipe HOTS. Aryani \& Maulida (2019), dalam penelitiannya menyimpulkan bahwa salah 
satu kendala ketidakmampuan siswa untuk menyelesaikan soal HOTS dalam matematika adalah karena rendahnya kemampuan penalaran dan berpikir kritis siswa dalam memahami informasi, dan mengidentifikasi permasalahan yang terdapat di dalam soal.

Berpikir kritis merupakan salah satu kompetensi yang diharapkan dapat dilatih melalui proses pembelajaran termasuk juga melalui pembelajaran matematika (Hudha \& Batlolona, 2017; Widana, dkk., 2018). Beberapa model pembelajaran matematika telah digunakan dengan tujuan untuk melatih siswa berpikir kritis, salah satunya adalah model 3CM (Cool-Critical-CreativeMeaningfull). Menurut Waluya \& Suyitno (2018), model 3CM merupakan penggabungan dari model pembelajaran kontekstual, matematika realistik, dan pembelajaran yang bermakna. Model ini memberikan pengalaman yang mengesankan dan memberi peluang siswa untuk memanfaatkan otak kanan dan kiri dalam kegiatan yang asik, kritis, kreatif, dan bermakna. Belajar dimulai dengan pemberian masalah kontestual yang dekat dengan aktifitas manusia, budaya, realitas social sehingga mudah diingatdan belajar menjadi berkesan (Waluya \& Suyitno, 2018).

Pada model pembelajaran 3CM terdapat empat aspek yaitu Cool, Critical, Creative, dan Meaningfull, dan di dalam aspek tersebut terdapat tujuh sintaks (Waluya \& Suyitno, 2018). Ketujuh sintaks pada model pembelajaran 3CM disajikan pada Tabel 1.

Tabel 1.

Sintak Model Pembelajaran 3CM

\begin{tabular}{ccc}
\hline $\begin{array}{c}\text { Aspe } \\
\mathrm{k}\end{array}$ & Sintaks & Tujuan \\
\hline
\end{tabular}

\begin{tabular}{|c|c|c|}
\hline $\begin{array}{l}\text { Cool } \\
\text { (Asik) }\end{array}$ & $\begin{array}{l}\text { 1. Memotiva } \\
\text { si } \\
\text { 2. Masalah } \\
\text { kontekstu } \\
\text { al }\end{array}$ & $\begin{array}{l}\text { Memberikan motivasi } \\
\text { siswa melalui masalah } \\
\text { kontekstual dalam } \\
\text { suasana belajar yang } \\
\text { menyenangkan serta } \\
\text { tahapan awal untuk } \\
\text { mengkritik masalah } \\
\text { kontekstual yang } \\
\text { diberikan. }\end{array}$ \\
\hline $\begin{array}{l}\text { Critical } \\
\text { (Kritis) }\end{array}$ & $\begin{array}{l}\text { 3. Mengeriti } \\
\text { k masalah } \\
\text { kontekstu } \\
\text { al. } \\
\text { 4. Pemecaha } \\
\text { n masalah }\end{array}$ & $\begin{array}{lr}\text { Siswa } & \text { diminta } \\
\text { memberikan } & \text { solusi } \\
\text { dari } & \text { masalah } \\
\text { kontekstual } & \text { dengan } \\
\text { mengkritik } & \text { terlebih } \\
\text { dahulu masalah yang } \\
\text { ada. }\end{array}$ \\
\hline $\begin{array}{l}\text { Creativ } \\
e \\
\text { (Kreatif } \\
\text { ) }\end{array}$ & $\begin{array}{l}\text { 5. Penerapan } \\
\text { konsep } \\
\text { pada } \\
\text { produk } \\
\text { kreatif }\end{array}$ & $\begin{array}{lr}\text { Siswa diharapkan } \\
\text { untuk memikirkan } \\
\text { potensi produk kreatif } \\
\text { yang mungkin } \\
\text { diproduksi sebagai } \\
\text { implementasi dari } \\
\text { konsep sebelumnya. }\end{array}$ \\
\hline $\begin{array}{l}\text { Meanin } \\
\text { gfull } \\
\text { (Berma } \\
\text { kna) }\end{array}$ & $\begin{array}{l}\text { 6. Konfirmasi } \\
\text { 7. Refleksi }\end{array}$ & $\begin{array}{lr}\text { Guru dan siswa } \\
\text { mendiskusikan } \\
\text { hasilnya } \\
\text { menemukan makna } \\
\text { dari yang telah } \\
\text { dipelajari, membuat } \\
\text { keputusan dalam } \\
\text { mengimplementasika } \\
\text { n konsep dalam } \\
\text { kehidupan. }\end{array}$ \\
\hline
\end{tabular}

Salah satu sintaks 3CM adalah Critical (Kritis), Melalui sintaks ini, siswa diminta untuk memberikan solusi dari masalah konstektual yang diberikan dengan cara mengkritik masalah tersebut terlebih dahulu. Namun demikian, belum ada penelitian yang memfokuskan untuk mengkaji dampak penggunaan model 3CM terhadap kemampuan berpikir kritis siswa.

Setelah aspek critical, guna mencapai meaningfull, terdapat aspek creative. Pada tahap ini siswa diharapkan menghasilkan suatu produk kreatif. Model ini tidak mengatur jenis produk kreatif yang harus dihasilkan. Oleh karenanya, penelitian ini 
membandingkan kemampuan berpikir kritis dari penerapan model 3CM dengan jenis produk kreatif yang berbeda yaitu kegiatan menghasilkan produk kreatif berupa proyek yaitu desain kemasan barang (karena model ini diterapkan pada materi jaring-jaring dan luas permukaan bangun ruang) dan produk kreatif berbasis problem posing, yang mana siswa diharapkan mampu menciptakan produk berupa masalah terkait bangun datar sekaligus memecahkan masalah tersebut.

Penerapan kedua desain pembelajaran berbasis model 3CM ini diharapkan dapat menjadi sarana untuk mengasah kemampuan berpikir kritis siswa serta dapat menginspirasi guru untuk menerapkan model $3 \mathrm{CM}$ ke dalam pembelajaran matematika pada materi lain atau bahkan dalam pembelajaran lainnya. Selain itu, hasil penelitian ini diharapkan dapat dijadikan dasar bahan kajian untuk penelitian lainnya.

\section{Metode}

Penelitian ini merupakan penelitian kuantitatif dengan jenis eksperimen semu (quasi experimental). Desain penelitian menggunakan Randomized control grup pretest-posttest design (Sukardi, 2005; Hardianto \& Baharuddin, 2019). Penelitian ini menguji keseimbangan kemampuan awal dari kedua kelas terlebih dahulu sebelum diberikan perlakuan, kemudian membandingkan kemampuan akhir kedua sampel setelah diberikan perlakuan untuk mengetahui dampak dari perbedaan perlakuan.

Penelitian ini dilaksanakan di SMP Negeri 1 Salatiga yang beralamat di Jalan Kartini No. 17 Kecamatan Sidorejo, Kota Salatiga,
Provinsi Jawa dan di SMP Negeri 6 Salatiga yang beralamat di Jalan Tegalrejo Raya No. 100 kecamatan Argomulyo, Kota Salatiga, Provinsi Jawa Tengah.

Penelitian bertujuan untuk mengetahui ada tidaknya perbedaan kemampuan berpikir kritis siswa dari penerapan model 3CM dengan bentuk produk kreatif berbeda. Penerapan model pembelajaran tersebut dilakukan pada bulan Oktober 2020 - Desember 2020 pada semester ganjil Tahun Ajaran 2020/ 2021.

Populasi penelitian ini adalah seluruh siswa SMP Negeri di Kota Salatiga. Melalui teknik pengambilan sampel cluster random sampling diperoleh 10 cluster (sekolah), dari 10 cluster dipilih 2 kelompok sampel secara acak sehingga diperoleh SMP Negeri 1 Salatiga dan SMP Negeri 6 Salatiga. Dari dua kelompok sampel tersebut dikelompokan kembali berdasarkan kelas masing-masing dan dipilih secara acak sehingga diperoleh kelas eksperimen 1 dengan jumlah sampel 41 siswa IXA SMP Negeri 1 Salatiga dan IXH SMP Negeri 6 Salatiga, sedangkan kelas eksperimen 2 terdiri dari 41 siswa IXF SMP Negeri 1 Salatiga dan IXA SMP Negeri 6 Salatiga.

Teknik pengumpulan data menggunakan metode observasi untuk mengukur keterlaksanaan penerapan kedua model pembelajaran serta aktifitas siswa selama proses pembelajaran dengan instrumen angket, dan metode tes dengan instrumen pretest dan posttest untuk mengukur kemampuan berpikir kritis siswa yang terdiri dari 3 soal berbentuk uraian.

Uji analisis data yang dilakukan yaitu uji kemampuan awal dan uji hipotesis. Sebelum dilakukan uji perbedaan, terlebih dahulu 
dilakukan uji normalitas. Setelah itu, dilakukan uji perbedaan dengan uji MannWhitney.

\section{Hasil dan Pembahasan}

Data kemampuan awal siswa diperoleh dari hasil pretest yang dilakukan oleh siswa kelas IXA \& IXF (SMP Negeri 1 Salatiga) dan kelas IXA \& IXH (SMP Negeri 6 Salatiga). Soal yang digunakan berupa 3 soal uraian (Gambar 1).

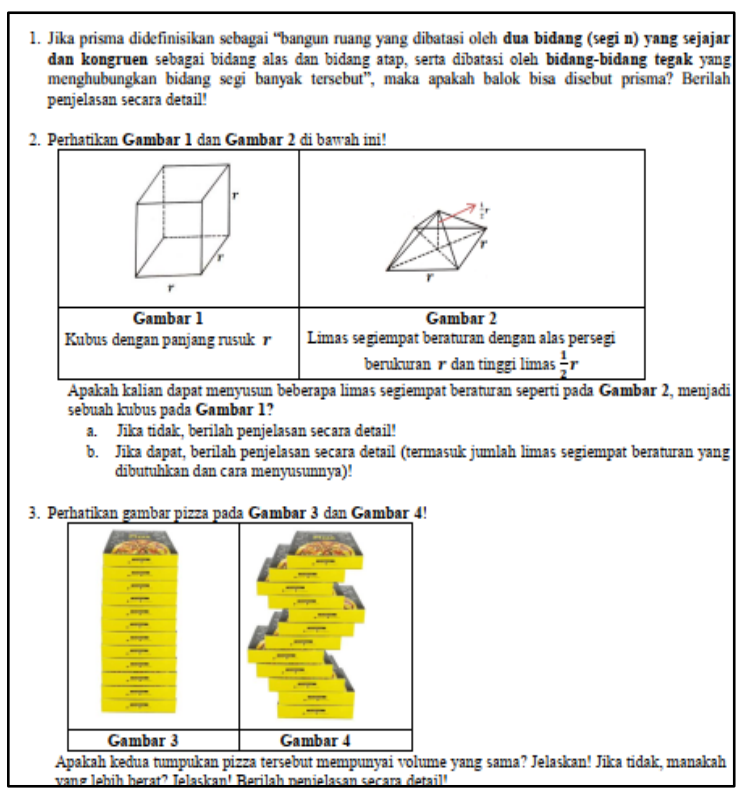

Gambar 1. Soal Berpikir Kritis untuk Pretest.

Hasil dari tes tersebut digunakan sebagai data kemampuan awal sebelum diberikan perbedaan perlakuan untuk masing-masing kelas. Rekapitulasi hasil tersebut dapat dilihat pada Tabel 2.

Tabel 2.

Data Kemampuan Awal Berpikir Kritis

\begin{tabular}{llllll}
\hline Kelas & $\mathrm{N}$ & Min & Max & Mean & St.Dev \\
\hline $\begin{array}{l}\text { Eksperimen } \\
1\end{array}$ & 41 & 30 & 100 & 67.45 & 3.464 \\
$\begin{array}{l}\text { Eksperimen } \\
2\end{array}$ & 41 & 30 & 100 & 74.77 & 3.476 \\
\hline
\end{tabular}

Pada Tabel 2 dapat dilihat bahwa jumlah sampel pada kelas eksperimen 1 dan eksperimen 2 masing-masing berjumlah 41 orang. Nilai minimum dan nilai maksimum antar kedua kelas juga sama dengan standar deviasi yang tidak jauh berbeda. Adapun nilai rata-rata kelas eksperimen $2(74,77)$ lebih tinggi dibandingkan nilai rata-rata kelas eksperimen 1 (67.45). Meskipun demikian, untuk menentukan kedua kelompok sampel memiliki kondisi awal yang seimbang atau tidak, diperlukan uji beda rerata. Guna menentukan uji beda rerata yang digunakan maka dilakukan uji normalitas. Kedua kelompok sampel samasama berjumlah 41 siswa, sehingga uji normalitas yang digunakan yaitu Kolmogorov Smirnov. Hasil uji normalitas dapat dilihat pada Tabel 3. Pada Tabel 3, tampak bahwa uji ini menghasilkan nilai signifikan sebesar 0,001 (kurang dari 0,05) untuk kelas eksperimen 1 dan tertulis .000 (artinya mendekati 0 yang kurang dari 0,05) untuk kelas eksperimen 2. Sehingga dapat disimpulkan bahwa kedua kelompok sampel tidak berasal dari populasi yang berdistribusi normal sehingga uji beda rerata menggunakan uji nonparametrik (Mann-Whitney).

Tabel 3.

Uji Normalitas Kemampuan Awal

\begin{tabular}{|c|c|c|c|c|}
\hline & \multicolumn{4}{|c|}{ Kolmogorov-Smirnov } \\
\hline & & Statistic & df & Sig. \\
\hline \multirow{2}{*}{ Pretest } & Eksperimen 1 & 159 & 41 & .011 \\
\hline & Eksperimen 2 & .208 & 41 & .000 \\
\hline
\end{tabular}

Hasil uji Mann-Whitney dapat dilihat pada Tabel 4. Uji ini menghasilkan nilai signifikan 0,105 (lebih dari 0,05). Oleh karena itu dapat disimpulkan bahwa kedua kelas eksperimen secara signifikan memiliki kemampuan awal berpikir kritis yang seimbang. 
Tabel 4.

Uji Mann-Whitney

\begin{tabular}{lr}
\hline Kepala Tabel & \multicolumn{1}{c}{ Kolom 1 } \\
\hline Mann-Whitney W & 666.000 \\
\hline Wilcoxon W & 1527.000 \\
\hline Z & -1.620 \\
\hline Asymp. Sig. (2-tailed) & .105 \\
\hline
\end{tabular}

Proses pelaksanaan pembelajaran dilakukan di SMP Negeri 1 Salatiga dan SMP Negeri 6 Salatiga, dengan menerapkan model 3CM dengan dua jenis kegiatan creative yang berbeda, dimana pada kelas eksperimen 1 siswa diminta menghasilkan produk berupa desain kemasan barang, sedangkan pada kelas eksperimen 2 siswa diminta menyusun masalah matematika dan memecahkannya. Kegiatan pembelajaran dilakukan selama 7 kali pertemuan secara daring menggunakan alat bantu laptop dan smartphone dengan menggunakan aplikasi seperti Zoom/ Google Meet untuk pembelajaran virtual, WhatsApp Grup (WAG) untuk komunikasi dan pembelajaran tanpa tatap muka, dan Google Clasroom untuk pengumpulan tugas. Dalam 7 kali pertemuan masingmasing pertemuan 2 jam pembelajaran sehingga total mencapai 14 jam pembelajaran. Materi yang diajarkan yaitu bangun ruang sisi datar dengan cakupan materi berupa jaring-jaring dan luas permukaan bangun ruang sisi datar (kubus, balok, prisma, dan limas).

Pada proses kegiatan pembelajaran baik kelas eksperimen 1 dan eksperimen 2, sama-sama menerapkan aspek 3CM. Pada aspek Cool (asik), guru memberikan motivasi kepada siswa dengan menunjukkan beragamnya kemasan produk yang dapat menarik minat pembeli. Aspek yang kedua yaitu Critical (kritis), siswa diminta menemukan solusi dari setiap permasalahan yang diberikan. Aspek yang ketiga yaitu Creative (kreatif), pada aspek ini siswa diminta untuk memikirkan potensi produk kreatif yang mungkin diproduksi sebagai implementasi dari konsep sebelumnya. Aspek yang keempat yaitu Meaningfull (bermakna), pada aspek ini guru dan siswa mendiskusikan hasilnya untuk menemukan makna dari yang telah dipelajari dan membuat keputusan dalam mengimplementasikan konsep dalam kehidupan nyata.

Pelaksanaan kegiatan pembelajaran baik di kelas eksperimen 1 maupun di kelas eksperimen 2 telah direncanakan sesuai dengan teori yang ada. Proses kegiatan pembelajaran juga telah dilaksanakan secara optimal sesuai dengan RPP yang telah disusun sebelumnya. Selama pengambilan data, peneliti bertindak sebagai guru dan guru bertindak sebagai observer untuk menilai keterlaksanaan model pembelajaran. Rekapulasi hasil observasi dari keterlaksanaan kedua model dapat dilihat pada Tabel 5. Berdasarkan hasil rekapulasi observasi pelaksanaan pembelajaran, tampak bahwa setiap aspek pada kedua model pembelajaran telah dilaksanakan dengan sangat baik.

Tabel 5.

Hasil Rekapulasi Observasi Pembelajaran

\begin{tabular}{lcc}
\hline $\begin{array}{l}\text { Aspek yang } \\
\text { diamati }\end{array}$ & \multicolumn{2}{c}{ Persentase } \\
\cline { 2 - 3 } & $\begin{array}{c}\text { (berbasis } \\
\text { project) }\end{array}$ & $\begin{array}{c}\text { 3CM } \\
\text { (berbasis } \\
\text { problems } \\
\text { posing) }\end{array}$ \\
\hline Perencanaan & $86,79 \%$ & $86,25 \%$ \\
\hline Pelaksanaan & $89,59 \%$ & $90,19 \%$ \\
\hline $\begin{array}{l}\text { Penguasaan } \\
\text { Materi }\end{array}$ & $90,76 \%$ & $92,19 \%$ \\
\hline
\end{tabular}




\begin{tabular}{lcc}
\hline $\begin{array}{l}\text { Penguasaan } \\
\text { Kelas }\end{array}$ & $86,16 \%$ & $87,50 \%$ \\
\hline $\begin{array}{l}\text { Sarana } \\
\begin{array}{l}\text { Pembelajaran } \\
\text { Daring }\end{array}\end{array}$ & $95,84 \%$ & $95,84 \%$ \\
\hline Kategori & Sangat Baik & Sangat Baik
\end{tabular}

Hasil kemampuan akhir siswa diambil setelah adanya perbedaan perlakuan. Siswa diberi soal posttest yang terdiri dari 4 soal uraian untuk mengukur kemampuan berpikir kritis siswa pada materi luas permukaan bangun ruang sisi datar. Soal dapat dilihat pada Gambar 2.

Hasil pekerjaan siswa atas soal posttest tersebut kemudian dipakai sebagai data kemampuan akhir. Rekapitulasi hasil tersebut dapat dilihat pada Tabel 6. Dalam Tabel 6 dapat diketahui bahwa dari kedua kelas, terdapat sampel yang dapat menghasilkan nilai maksimum 100. Dengan melihat nilai minimum dan rata-rata, kelas eksperimen 2 lebih unggul dibanding dengan kelas eksperimen 1. Selain itu, nilai standar deviasi kelas ekperimen 2 lebih rendah dibandingkan kelas eksperimen 1 . Hal ini menunjukkan kemampuan sampel pada kelas eksperimen dua lebih homogen.

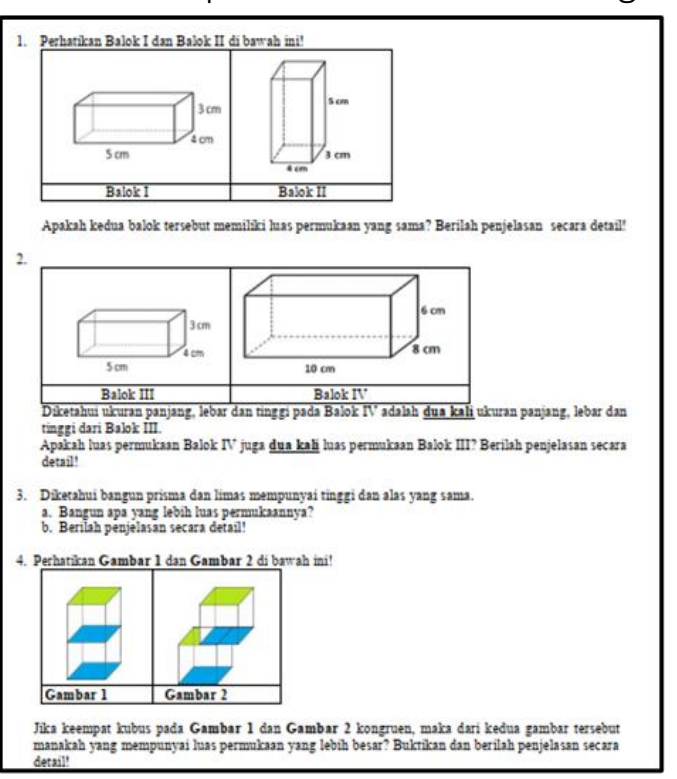

Gambar 2. Soal Berpikir Kritis untuk Posttest
Tabel 6.

Data Kemampuan Akhir Berpikir Kritis

\begin{tabular}{|c|c|c|c|c|c|}
\hline Kelas & $\mathrm{N}$ & Min & $\begin{array}{c}\text { Ma } \\
\mathbf{x} \\
\end{array}$ & $\begin{array}{c}\text { Mea } \\
\mathrm{n}\end{array}$ & $\begin{array}{c}\text { St.De } \\
\mathbf{v}\end{array}$ \\
\hline Eksperimen & 4 & 46.6 & 100 & 83.7 & 2.464 \\
\hline 1 & 1 & 7 & & 1 & \\
\hline Eksp & 4 & 56.6 & 100 & 89.3 & 1.689 \\
\hline 2 & 1 & 7 & & 9 & \\
\hline
\end{tabular}

Meskipun data sampel menunjukkan ada perbedaan rerata, namun untuk menarik simpulan pada populasi tetap perlu dilakukan uji beda rerata untuk kedua kelas. Seperti halnya pada kemampuan awal, dilakukan uji normalitas dengan Kolmogorov Smirnov guna menentukan jenis uji beda rerata yang akan digunakan. Hasil uji normalitas data ini dapat dilihat pada Tabel 7.

Tabel 7.

Hasil Uji Normalitas Kemampuan Akhir

\begin{tabular}{|c|c|c|c|c|}
\hline & \multicolumn{4}{|c|}{ Kolmogorov-Smirnov } \\
\hline & Kelas & Statistic & $\mathrm{df}$ & Sig. \\
\hline \multirow{2}{*}{ Posttest } & $\begin{array}{c}\text { Eksperimen } \\
1\end{array}$ & .265 & 41 & .000 \\
\hline & $\begin{array}{c}\text { Eksperimen } \\
2\end{array}$ & .247 & 41 & .000 \\
\hline
\end{tabular}

Pada Tabel 7 terlihat bahwa siginifikansi uji normalitas pada kolom Kolmogorov Smirnov untuk kedua kelas tertulis .000 (artinya 0 yang kurang dari 0,05 ) sehingga kedua kelas tersebut tidak berasal dari populasi yang berdistribusi normal. Oleh karena itu uji statistik yang digunakan adalah uji non-parametik (Mann-Whitney). Uji Mann-Whitney disajikan pada Tabel 8.

Tabel 8.

Uji Mann-Whitney

\begin{tabular}{lr}
\hline Kepala Tabel & \multicolumn{1}{c}{ Kolom 1 } \\
\hline Mann-Whitney W & 649.500 \\
\hline Wilcoxon W & 1510.500 \\
\hline Z & -1.780 \\
\hline Asymp. Sig. (2-tailed) & .075 \\
\hline
\end{tabular}


Pada Tabel 8 diketahui bahwa uji MannWhitney menghasilkan nilai signifikan 0,075 (lebih dari 0,05). Oleh karena itu dapat disimpulkan bahwa penerapan 3CM dengan dua jenis kegiatan kreatif berbeda tidak menghasilkan kemampuan berpikir kritis yang berbeda.

Perancangan dan pelaksanaan kedua model dilakukan secara optimal serta sesuai konteks kehidupan sehari-hari melalui pembelajaran yang asik dan menyenangkan mampu menarik perhatian siswa untuk belajar dan juga mengkritisi permasalahan kontekstual maupun konsep-konsep dalam matematika. Sehingga meskipun dilanjutkan dengan kegiatan creative yang berbeda siswa tetap dapat mengasah kemampuan berpikir kritis dari kegiatan tersebut. Melalui kegiatan mendesain kemasan (berbasis project) dan juga melalui kegiatan menyusun masalah untuk diselesaikan (berbasis problems posing), siswa samasama dituntut mengkritisi beberapa hal untuk dapat menghasilkan produk tersebut. Sebelum menghasilkan produk berupa desain siswa dilatih untuk berpikir kritis dengan memberikan kesempatan bagi siswa untuk berpendapat/ beragumen menyampaikan ide-ide atau stategi yang digunakan untuk menghasilkan desain kemasan yang unik dan menarik. Sementara, siswa yang diminta menyusun masalah matematika dan memecahkannya, dalam menyusun masalah tersebut siswa dilatih mengkritisi indikator permasalahan ataupun contoh permasalahan agar dapat menyusun masalah sesuai dengan kriteria yang diberikan. Tidak hanya menyusun, namun siswa juga diminta mengkaji perbedaan masalah yang disusun dengan contoh. Selain itu, siswa juga diminta memecahkan masalah tersebut dengan terlebih dahulu mengkaji langkah solusi dari contoh masalah yang diberikan.

Kurniawan \& Wuryandani (2017) dalam penelitiannya menyatakan bahwa model pembelajaran berbasis masalah mampu melatih kemampuan berpikir kritis, dikarenakan adanya permasalahan kontekstual yang memicu rasa ingin tau siswa dalam pemecahan masalah tersebut. Sementara hasil penelitian Holmes \& Hwang (2016) menunjukkan adanya dampak positif pemberian proyek terhadap kemampuan berpikir kritis siswa, dengan adanya pengerjaan proyek oleh siswa dapat mengasah kemampuan berpikir kritis siswa. Sejalan dengan hal tersebut, hasil penelitian Rahayu \& Hartono (2016) menyimpulkan bahwa tidak ada perbedaan kemampuan berpikir kritis siswa dari penerapan model pembelajaran berbasis proyek dengan yang berbasis masalah. Jadi meskipun bentuk kegiatan creative berbeda, namun jika keduanya dilakukan secara optimal maka akan berdampak yang sama. Hal ini sesuai dengan pendapat Samura (2019), Afriansyah (2021), dan Lestari (2021) yang menyatakan bahwa berpikir kreatif adan berpikir kritis merupakan dua sisi yang tidak dapat dilepaskan.

Berdasarkan hasil penelitian, dapat disimpulkan bahwa penerapan model pembelajaran 3CM dengan dua jenis kegiatan creative yang berbeda, mampu menghasilkan kemampuan berpikir kritis yang sama. Hal ini sejalan dengan penelitian Mulyono, Ardiansyah, Fariz, \& Khoirunnisa (2020). 


\section{Penutup}

Berdasarkan hasil penelitian maka dapat disimpulkan bahwa penerapan model 3CM dengan bentuk kegiatan creative yang berbeda (berbasis project dan berbasis problems posing) tidak menghasilkan perbedaan kemampuan berpikir kritis siswa. Hasil tersebut menunjukkan bahwa dalam penerapan 3CM, dimungkinkan untuk menggunakan dua jenis kegiatan tersebut untuk melakukan aspek creative guna mengasah kemampuan berpikir kritis siswa.

Berdasarkan hasil penelitian ini, muncul suatu pertanyaan apakah terdapat perbedaan kemampuan berpikir kritis yang signifikan antara siswa yang dituntut untuk berkreasi dengan siswa yang tidak dituntut untuk berkreasi. Hal ini dapat dijadikan rumusan masalah untuk penelitian selanjutnya.

\section{DAfTAR PUstaka}

Abidin, Z., Hudaya, A., \& Anjani, D. (2020). Efektivitas Pembelajaran Jarak Jauh Pada Masa Pandemi Covid-19. Research and Development Journal of Education, 1(1), 131.

Afriansyah, E. A. (2021). Realistic Mathematics Education Berbasis Emergent Modeling untuk Meningkatkan Kemampuan Berpikir Kritis dan Kreatif Matematis serta Curiosity Mahasiswa Calon Guru (Doctoral dissertation, Universitas Pendidikan Indonesia).

Apiati, V., \& Hermanto, R. 2020. Kemampuan Berpikir Kritis Peserta Didik dalam Memecahkan Masalah Matematik Berdasarkan Gaya Belajar.
Mosharafa: Jurnal Pendidikan Matematika, 9 (1), 49-60, 167-178.

Aryani, I., \& Maulida. (2019). Analisis Kesalahan Siswa Dalam Menyelesaikan Soal Matematika Melalui Higher Order Thinking Skills (HOTS). Jurnal Serambi IImu, 20(2), 274-290.

Baharuddin, I. (2020). Pembelajaran bermakna berbasis daring di tengah pandemi covid-19. Journal of Islamic Education Management, 5(2), 79-88.

Boer, K. M., Pratiwi, M. R., \& Muna, N. (2020). Analisis Framing Pemberitaan Generasi Milenial dan Pemerintah Terkait Covid-19 di Media Online. Communicatus: Jurnal IImu Komunikasi, 4(1), 85-104.

Choy, S. C., \& Cheah, P. K. (2009). Teacher Perceptions of Critical Thinking Among Students and its Influence on Higher Education. 20(2), 198-206.

Dewi, D. P., Mediyani, D., Hidayat, W., Rohaeti, E. E., \& Wijaya, T. T. (2019). Analisis Kemampuan Berpikir Kritis Matematis Siswa Smp Pada Materi Lingkaran Dan Bangun Ruang Sisi Datar. JPMI (Jurnal Pembelajaran Matematika Inovatif), 2(6), 371.

Dewi, W. A. F. (2020). Dampak COVID-19 terhadap Implementasi Pembelajaran Daring di Sekolah Dasar. Edukatif: Jurnal IImu Pendidikan, 2(1), 55-61.

Handaka, B. I., \& Safitri, N. E. (2016). Pemanfaatan Metode Experiential Learning Untuk Meningkatkan Keterampilan Berpikir Kritis Siswa Dalam Belajar. Seminar Nasional Optimalisasi Active Learning Dan Character Building Dalam Meningkatkan Daya Saing Bangsa Di 
Era Masyarakat Ekonomi Asean (MEA)., 157-164.

Hardianto, H., \& Baharuddin, M. R. (2019). Efektifitas Penerapan Model Pembelajaran PAIKEM Gembrot terhadap Peningkatan Hasil Belajar Mahasiswa pada Mata Kuliah Pembelajaran Matematika Sekolah Dasar. Cokroaminoto Journal of Primary Education, 2(1), 27-33.

Holmes, V. L., \& Hwang, Y. (2016). Exploring the effects of project-based learning in secondary mathematics education. Journal of Educational Research, 109(5), 449-463.

Hudha, M. N., \& Batlolona, J. R. (2017). How are the physics critical thinking skills of the students taught by using inquirydiscovery through empirical and theorethical overview?. Eurasia Journal of Mathematics, Science and Technology Education, 14(2), 691-697. Kurniawan, M. W., \& Wuryandani, W. (2017). Pengaruh model pembelajaran berbasis masalah terhadap motivasi belajar dan hasil belajar PPKn. Jurnal Civics: Media Kajian Kewarganegaraan, 14(1), 10-22.

Larsson, K. (2017). Understanding and teaching critical thinking - A new approach. 84(December 2016), 32-42. Lestari, N. (2021). Pengembangan Lembar Kerja Siswa (LKS) Berbasis Guided Inquiry untuk Meningkatkan Kemampuan Berpikir Kritis Siswa SMP Muhammadiyah Kupang. Jurnal Biosains dan Edukasi, 2(1), 10-15.

Mahardiningrum, A. S. (2018). Profil Pemecahan Masalah Matematika Siswa SMP Pangudi. Mosharafa: Jurnal
Pendidikan Matematika, 7(1), 75-84. Mulyono, M., Ardiansyah, A. S., Fariz, R., \& Khoirunnisa, K. (2020). Prespektif Gender terhadap Kemampuan Berpikir Kreatif Mahasiswa pada Blended Learning berbantu Google Classrooms. Kreano, Jurnal Matematika Kreatif-Inovatif, 11(2), 270-282.

Nurdin, \& Anhusadar, L. O. (2021). Efektifitas Pembelajaran Online Pendidik PAUD di Tengah Pandemi Covid 19. Jurnal Obsesi: Jurnal Pendidikan Anak Usia Dini, 5(1), 686697.

Nurhikmayati, I., \& Jatisunda, M. G. (2019). Pengembangan Bahan Ajar Matematika Berbasis Scientific yang Berorientasi pada Kemampuan Berpikir Kritis Matematis Siswa. Mosharafa: Jurnal Pendidikan Matematika, 8(1), 49-60.

Prawiyogi, A. G., Purwanugraha, A., Fakhry, G., \& Firmansyah, M. (2020). Efektifitas Pembelajaran Jarak Jauh Terhadap Pembelajaran Siswa di SDIT Cendekia Purwakarta. Jurnal Pendidikan Dasar, 11(1), 94-101.

Rahayu, E., \& Hartono, H. (2016). Keefektifan Model PBL dan PjBL ditinjau dari Prestasi, Kemampuan Berpikir Kritis, dan Motivasi Belajar Siswa SMP. Journal Pendidikan Matematika, 11(1), 1.

Rizky, E. N. F., \& Sritresna, T. (2021). Peningkatan Kemampuan Berpikir Kritis dan Disposisi Matematis Siswa Antara Guided Inquiry dan Problem Posing. PLUSMINUS: Jurnal Pendidikan Matematika, 1(1), 33-46. 
Ruqoyyah, S., Murni, S., \& Wijaya, T. T. (2020). The Effect of VBA for Microsoft Excel as Teaching Material to Improve Prospective Elementary School Teachers' Mathematical Conceptual Understanding. Mimbar Sekolah Dasar, 7(2), 251-268.

Samura, A. O. (2019). Kemampuan Berpikir Kritis dan Kreatif Matematis Melalui Pembelajaran Berbasis Masalah. MES: Journal of Mathematics Education and Science, 5(1), 20-28.

Sarimanah, T. (2017). Meningkatkan

Kemampuan Berpikir Kritis. Jurnal Prisma, 6(2), 101-107.

Sukardi. (2005). Metodologi Penelitian Pendidikan Kompetensi dan Praktiknya. Jakarta: Bumi Aksara.

Suni Astini, N. K. (2020). Tantangan Dan Peluang Pemanfaatan Teknologi Informasi Dalam Pembelajaran Online Masa Covid-19. Cetta: Jurnal IImu Pendidikan, 3(2), 241-255.

Susilowati, Sajidan, \& Ramli, M. (2017). Analisis keterampilan berpikir kritis siswa madrasah aliyah negeri di Kabupaten Magetan. Seminar Nasional Pendidikan Sains 2017 Dengan Tema "Strategi Pengembangan Pembelajaran Dan Penelitian Sains Untuk Mengasah Keterampilan Abad 21 (Creativity and Innovation, Critical Thinking and Problem Solving, Communication, Collaboration/4C)", 21(2000), 223-231.

Waluya, S. B., \& Suyitno, H. (2018). Effectiveness of 3CM Learning Model with Blended Learning on Improving Creative Thinking Ability in Mathematical Problem Solving.
247(Iset), 577-582.

Wicaksono, B. D., \& Prihatnani, E. (2019). Profil Berpikir Kritis Matematis Mahasiswa dalam Menyelesaikan Soal Trigonometri Ditinjau dari Tingkat Kepercayaan Diri. Mosharafa: Jurnal Pendidikan Matematika, 8(1), 71-82.

Widana, I. W., Parwata, I., Parmithi, N. N., Jayantika, I. G. A. T., Sukendra, I. K., \& Sumandya, I. W. (2018). Higher order thinking skills assessment towards critical thinking on mathematics lesson. International journal of social sciences and humanities, 2(1), 24-32.

Wijaya, T. T., Ying, Z., \& Suan, L. (2020). Gender and Self Regulated Learning During COVID-19 Pandemic in Indonesia. Jurnal Basicedu, 4(3), 725732.

\section{Riwayat Hidup Penulis}

\section{Titania Mega Rizti.}

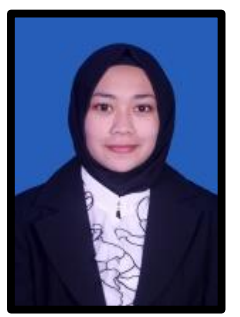

Lahir di Magelang 15 Agustus 1999. Studi S1 Pendidikan Matematika Universitas Kristen Satya Wacana.

Erlina Prihatnani, S.Si., M.Pd.

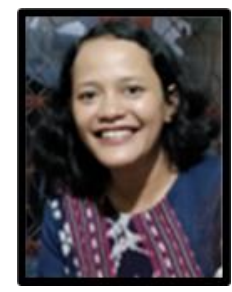

Lahir di Purworejo, 10 Agustus 1984. Dosen Program Studi Pendidikan Matematika Universitas Kristen Satya Wacana, Salatiga memperoleh gelar S1 Matematika FSM Universitas Kristen Satya Wacana, kemudian melanjutkan studi dan memperoleh gelar S2 di Universitas Sebelas Maret Surakarta. 